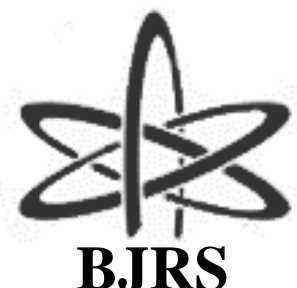

BJRS
BRAZILIAN JOURNAL

$\mathrm{OF}$

RADIATION SCIENCES

07-02A (2019) 01-09

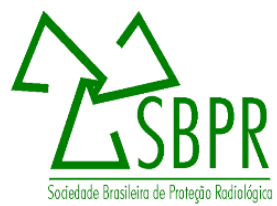

\title{
Neutron Activation Analysis characterization procedures for fish consumed at São Paulo City
}

\author{
B. Tappiz ${ }^{\text {a. }}$ E. G. Moreira ${ }^{\text {a }}$ \\ ${ }^{a}$ Instituto de Pesquisas Energéticas e Nucleares, IPEN - CNEN/SP, Avenida Prof. Lineu Prestes, 2242 \\ CEP 05508-000, São Paulo, São Paulo, Brazil \\ brunotappiz2@gmail.com
}

\begin{abstract}
The characterization of edible tissues of fishes consumed by humans is very important for determination of several toxic and potentially toxic elements, ensuring the food safety. The Instrumental Neutron Activation Analysis (INAA) comparative method allows the determination of several of these elements, as well as others, for example of nutritional character. This study is part of an International Atomic Energy Agency (IAEA) technical cooperation project of Latin America and Caribbean countries to ensure the quality of food and biomonitoring of contaminants in shellfish and fishes. Ten specimens of 4 of the most consumed fish in São Paulo city: whitemouth croaker (Micropogonias Furnieri), smooth weakfish (Cynoscion learchus), common snook (Centropomus undecimalis) and Brazilian sardine (Sardinella brasiliensis) were analyzed. Complete procedures for analysis, which includes purchase in the largest warehouse in Latin America, transport to the laboratory, storage, freeze-drying, milling, weighting and others preparations of the subsamples, and the short irradiation parameters for the determination of $\mathrm{Br}, \mathrm{Cl}, \mathrm{K}, \mathrm{Mg}, \mathrm{Mn}$ and $\mathrm{Na}$ are reported. Results obtained under the same irradiation conditions for reference materials (oyster and mussel tissues) for macro and microelements are presented and are in agreement with their certificates, which indicate that the performed analyses were appropriate. Regarding to the mass fraction values obtained for the fish samples, they were in agreement with the literature.
\end{abstract}

ISSN: 2319-0612 


\section{INTRODUCTION}

Fish consumption is important for human health due to its benefits [1] as content of high-quality protein, vitamins, essential nutrients, and two kinds of omega-3: eicosapentaenoic acid (EPA) and docosahexanoic acid (HPA) [2].

Despite the benefits of fish consumption and Brazil having an extensive coastline, the Brazilian population only reached the consumption recommended by World Health Organization (WHO) of 12 kg/year person, according the Ministry of Fisheries and Agriculture in 2013 [3].

Inorganic contaminants are present in the aquatic environment, coming from natural and anthropogenic sources. The problematic of these contaminants occurs by the following steps: inorganic contaminants are present in the sediment, which provides habitat and food for benthos and fish, bioaccumulation and biomagnification may exist from food web relationships $[4,5]$ and humans can be exposed to the inorganic contaminants by feeding on fishes [6].

Considering the risks and benefits, researchers [7, 8] have produced studies in this area of fish evaluation.

This paper describes procedures for analysis of micro, macro and toxic elements in fish by the comparative INAA technique, in the framework of a Technical Cooperation Project of the International Atomic Energy Agency (IAEA) for Latin American and Caribbean countries in assurance of food quality and biomonitoring of contaminants in shellfish and fish (Project Number RLA/5/054, ARCAL CIII) [9].

\section{MATERIALS AND METHODS}


This study reports from the purchase of fishes to the subsample preparation for irradiation, and the parameters for the determined elements by INAA.

\subsection{Fish Sampling}

Ten individuals of the species most commercialized at São Paulo city: whitemouth croaker ( $M i$ cropogonias Furnieri), smooth weakfish (Cynoscion learchus), common snook (Centropomus undecimalis) and Brazilian sardine (Sardinella brasiliensis), were purchase in the largest warehouse of Latin America, being transported between layers of ice to the Neutron Activation Analysis Laboratory (IPEN - CNEN/SP). The fish remained in refrigerators until the time of their preparation.

\subsection{Sample preparation}

After the samples were purchased, they were weighed, washed with purified water (Milli-Q), the tissues commonly edible by Brazilians were freeze-dried (Thermo Savant Modulyo D, Thermo Electron Corporation), milled in blender adapted with titanium blades, homogenized and stored in decontaminated flasks. The residual humidity content was measured before the analysis by the oven drying method until constant mass was obtained.

\subsection{Instrumental Neutron Activation Analysis (INAA)}

Approximately $200 \mathrm{mg}$ of the powdered samples were weighted in analytical balance (Shimadzu AEM-5200) in previously decontaminated $1.8 \times 1.8 \mathrm{~cm}$ polyethylene bag ( $24 \mathrm{~h}$ in $10 \% \mathrm{v} / \mathrm{v}$ Merck $\mathrm{HNO}_{3}$ ) and sealed (Selapack). A similar procedure was performed for two certified reference materials (CRM) Perna perna mussel [10] and NIST SRM 1566b, Oyster Tissue [11].

Elemental standard solutions (Spex CertiPrep) were pipetted into filter papers strips (Whatman 40) using Eppendorf pipettes with previously checked nominal volumes. For some elements, it was necessary to dilute the standard solutions in a $10 \mathrm{~mL}$ volumetric flask before pipetting them. The 
papers strips were dried at room temperature in a laminar flow hood then were folded and placed in polyethylene bags of the same sample size.

Each irradiation batch consisted of a sample or CRM and elemental standards. They were irradiated in the IEA-R1 Nuclear Reactor (IPEN - CNEN/SP) by the pneumatic station for $20 \mathrm{~s}$ under thermal neutron flux of approximately $1.9 \times 10^{12} \mathrm{~cm}^{-2} \mathrm{~s}^{-1}$.

After irradiation, the elements $\mathrm{Br}, \mathrm{Cl}, \mathrm{K}, \mathrm{Mg}, \mathrm{Mn}$ and $\mathrm{Na}$ were determined by gamma spectrometry of radionuclides of these elements, performed in a CANBERRA HPGe detector (model GC2018) coupled to CANBERRA DSA 1000 digital spectral analyzer. Further information about the pipetted standards and radionuclides used for the element determinations is show in Table 1.

Table 1: Parameters of radionuclides and pipetted standards used in comparative INAA [12].

\begin{tabular}{ccccc}
\hline Element & Radionuclide & $\begin{array}{c}\text { Energy used for } \\
\text { calculations, keV }\end{array}$ & Half-Life & $\begin{array}{c}\text { Element mass in pi- } \\
\text { petted standard, } \boldsymbol{\mu g}^{\mathbf{a}}\end{array}$ \\
\hline Bromine & ${ }^{80} \mathrm{Br}$ & 616.3 & $17.68 \mathrm{~min}$ & $4.878 \pm 0.087$ \\
Chlorine & ${ }^{38} \mathrm{Cl}$ & 1642.7 & $37.24 \mathrm{~min}$ & $247 \pm 11$ \\
Potassium & ${ }^{42} \mathrm{~K}$ & 1524.6 & $12.360 \mathrm{~h}$ & $995 \pm 12$ \\
Magnesium & ${ }^{27} \mathrm{Mg}$ & 843.3 & $9.458 \mathrm{~min}$ & $993 \pm 12$ \\
Manganese & ${ }^{56} \mathrm{Mn}$ & 846.8 & $2.5785 \mathrm{~h}$ & $4.902 \pm 0.087$ \\
Sodium & ${ }^{24} \mathrm{Na}$ & 1368.6 & $14.9590 \mathrm{~h}$ & $195.2 \pm 3.4$ \\
\hline
\end{tabular}

${ }^{\mathrm{a}}$ Expanded uncertainty, $k=2$

Regarding the measuring conditions, standards of the radionuclide ${ }^{27} \mathrm{Mg}$ were measured for a period of $300 \mathrm{~s}$, followed by ${ }^{80} \mathrm{Br},{ }^{38} \mathrm{Cl},{ }^{42} \mathrm{~K},{ }^{56} \mathrm{Mn}$ and ${ }^{24} \mathrm{Na}$ standards for $1,800 \mathrm{~s}$. Subsamples were measured twice, just after leaving the reactor for a period of $300 \mathrm{~s}$, and after 2,700 s decay for 3,600 s. The calculation of mass fractions was performed using Microsoft Excel.

\section{RESULTS AND DISCUSSION}

\subsection{Quality Control}


Results obtained experimentally by the comparative method of INAA for the Perna perna mussel and Oyster Tissue 1556b CRMs, their certified values and calculation of z-scores are presented in Table 2. The z-score was obtained using the modified Horvitz equation [13]. The Oyster Tissue has no certified and reference value for $\mathrm{Br}$.

Table 2: Mass fractions obtained by comparative INAA (mean values and expanded uncertainties, $k=2$, dry weight, $n=5$ ) and the certified values of reference materials.

\begin{tabular}{ccccc}
\hline & \multicolumn{4}{c}{ CRM } \\
\cline { 2 - 5 } Element & Perna Perna Mussel & \multicolumn{2}{c}{ Oyster Tissue 1556b } \\
\cline { 2 - 5 } & $\begin{array}{c}\text { Obtained value } \\
\text { (certified value) }\end{array}$ & z-score & $\begin{array}{c}\text { Obtained value } \\
\text { (certified value) }\end{array}$ & z-score \\
\hline \multirow{2}{*}{ Br (mg kg-1) } & $245 \pm 28$ & -0.16 & $52.2 \pm 5.4$ & - \\
& $(248 \pm 42)^{\mathrm{i}}$ & & & \\
Cl (\%) & $3.822 \pm 0.076$ & 1.0 & $(0.523 \pm 0.013$ & 0.35 \\
& $(3.69 \pm 0.57)$ & & $0.585 \pm 0.032$ & \\
K (\%) & $0.866 \pm 0.088$ & 1.3 & $(0.652 \pm 0.009)$ & -2.5 \\
Mg (\%) & $(0.82 \pm 0.13)$ & & $0.1083 \pm 0.0092$ & -0.02 \\
& $0.405 \pm 0.031$ & 1,6 & $(0.1085 \pm 0.0023)$ & \\
Mn (mg kg-1) & $(0.373 \pm 0.056)$ & & $16.27 \pm 0.36$ & -1.2 \\
& $22,91 \pm 0,50$ & 0,08 & $(18.5 \pm 0.2)$ & \\
Na (\%) & $(23.4 \pm 3.1)$ & & $0.2840 \pm 0.0040$ & -3.2 \\
\hline
\end{tabular}

informative value

It is considered criteria to approval values $|z|<3$, which means that the CRM should be in the approximately $99 \%$ confidence interval of the certified value [14]. Values of z-score varied between \pm 3 , except for $\mathrm{Na}$ in the SRM 1556b, which indicates good accuracy for determination of the mass fraction of $\mathrm{Br}, \mathrm{Cl}, \mathrm{K}, \mathrm{Mg}$ and $\mathrm{Mn}$ in the simple fish under the same analysis conditions. 


\subsection{Mass Fraction Determination in Fish Samples}

Table 3 shows the mean mass fraction of $\mathrm{Br}, \mathrm{Cl}, \mathrm{K}, \mathrm{Mg}, \mathrm{Mn}$ and $\mathrm{Na}$ of ten specimens of each species. It was decided to reports the results with the standard deviation, as the natural variation of the specimens is higher than the imprecision associated with the respective input quantities into account in this study.

Table 3: Element mass fraction in wet weight in fish samples (mean \pm SD and range in parenthesis).

\begin{tabular}{|c|c|c|c|c|}
\hline \multirow[b]{2}{*}{ Element } & \multicolumn{4}{|c|}{ Fish species } \\
\hline & $\begin{array}{c}\text { Cynoscion lei- } \\
\text { archus }\end{array}$ & $\begin{array}{c}\text { Centropomus } \\
\text { undecimalis }\end{array}$ & $\begin{array}{l}\text { Micropogonias } \\
\text { furnieri }\end{array}$ & $\begin{array}{c}\text { Sardinella } \\
\text { brasiliensis }\end{array}$ \\
\hline $\begin{array}{c}\text { Br, } \\
\text { mg kg-1 }^{-1}\end{array}$ & $\begin{array}{c}7.2 \pm 2.1 \\
(4.1-12.0)\end{array}$ & $\begin{array}{c}4.9 \pm 1.2 \\
(3.0-6.9)\end{array}$ & $\begin{array}{c}4.17 \pm 0.62 \\
(3.11-5.14)\end{array}$ & $\begin{array}{c}4.09 \pm 0.63 \\
(3.17-4.90)\end{array}$ \\
\hline $\begin{array}{c}\mathrm{Cl}, \\
\mathrm{g} \mathrm{kg}^{-1}\end{array}$ & $\begin{array}{c}1.63 \pm 0.39 \\
(0.96-2.39)\end{array}$ & $\begin{array}{c}0.80 \pm 0.17 \\
(0.59-1.05)\end{array}$ & $\begin{array}{c}0.943 \pm 0.070 \\
(0.831-1.052)\end{array}$ & $\begin{array}{c}0.945 \pm 0.097 \\
(0.817-1.122)\end{array}$ \\
\hline $\begin{array}{c}\mathrm{K}, \\
\mathrm{g} \mathrm{kg}^{-1}\end{array}$ & $\begin{array}{c}3.28 \pm 0.58 \\
(2.72-4.73)\end{array}$ & $\begin{array}{c}3.62 \pm 0.26 \\
(3.08-3.92)\end{array}$ & $\begin{array}{c}3.52 \pm 0.46 \\
(2.93-4.48)\end{array}$ & $\begin{array}{c}5.1 \pm 1.5 \\
(3.9-8.9)\end{array}$ \\
\hline $\begin{array}{l}\text { Mg, } \\
\text { g kg-1 }^{-1}\end{array}$ & $\begin{array}{c}0.258 \pm 0.036 \\
(0.207 \pm 0.307)\end{array}$ & $\begin{array}{c}0.277 \pm 0.037 \\
(0.191-0.321)\end{array}$ & $\begin{array}{c}0.244 \pm 0.027 \\
(0.181-0.273)\end{array}$ & $\begin{array}{c}0.394 \pm 0.056 \\
(0.296-0.463)\end{array}$ \\
\hline $\begin{array}{c}\mathrm{Mn}, \\
\mathrm{mg} \mathrm{kg}^{-1}\end{array}$ & $\begin{array}{c}0.096 \pm 0.025 \\
(0.060-0.145)\end{array}$ & $\begin{array}{c}0.065 \pm 0.017 \\
(0.037-0.084)\end{array}$ & $\begin{array}{c}0.100 \pm 0.038 \\
(0.045-0.183)\end{array}$ & $\begin{array}{c}0.67 \pm 0.43 \\
(0.36-1.77)\end{array}$ \\
\hline $\begin{array}{l}\mathrm{Na}, \\
\mathrm{g} \mathrm{kg}^{-1}\end{array}$ & $\begin{array}{c}1.10 \pm 0.32 \\
(0.82-1.60)\end{array}$ & $\begin{array}{c}0.615 \pm 0.058 \\
(0.504-0.689)\end{array}$ & $\begin{array}{c}0.686 \pm 0.089 \\
(0.579-0.834)\end{array}$ & $\begin{array}{c}0.642 \pm 0.071 \\
(0.549-0.775)\end{array}$ \\
\hline
\end{tabular}

Similar results were obtained for the $\mathrm{Br}, \mathrm{K}$ and $\mathrm{Na}$ elements in Cynoscion leiarchus, Centropomus undecimalis, Micropogonias furnieri and Sardinella brasiliensis analyzed by INAA in other study [15]. In both cases, $\mathrm{K}$ mass fractions were the highest for the analyzed elements.

This paper is part of a study that is based on the analysis of toxic elements, and therefore on food safety. Results for micro and macro elements are presented because the technique used has multielemental character in addition to being useful database for possible futures discussions. Long irra- 
diations of this samples were carried out in a previous study [15] which allowed the comparison of the toxic elements As, Se and Zn mass fractions with the national and international legislations [16, 17].

For these samples, it is still interest in the food safety scope, perform As speciation to verify the inorganic species amount, that will be performed by Graphite Furnace Atomic Absorption Spectrometry (GF AAS).

Based in this methodology, which seem appropriate for the fish analysis by INAA, another 20 specimens of 2 species of fish: bluefish (Pomatomus saltatrix) and lebranche mullet (Mugil brasiliensis) will be prepared for the long and short irradiation analysis.

\section{CONCLUSION}

The procedure for the characterization of edible fish tissues by INAA was adequate, with satisfactory z-score results for the used CRMs under the same irradiation condition. Obtained results for $\mathrm{Br}, \mathrm{Cl}, \mathrm{K}, \mathrm{Mg}, \mathrm{Mn}$ and $\mathrm{Na}$ in Micropogonias Furnieri, Cynoscion learchus, Centropomus undecimalis and Sardinella brasiliensis, four of the most consumed fish species in São Paulo city, are in accordance with previous studies and will also be applied to the analysis of tissues of other two edible fishes (Pomatomus saltatrix and Mugil brasiliensis). Although food safety has been discussed in this paper, conclusions in this direction require further analyses, such arsenic speciation, which will be carried out in a near future.

\section{ACKNOWLEDGMENT}

Authors acknowledge the financial support provided by Brazilian National Nuclear Energy Commission (CNEN), the Brazilian National Council of Scientific and Technological Development (CNPq), the São Paulo Research Foundation (FAPESP Process 2015/10774-9 and Process 2009/01452-7) and the International Atomic Energy Agency (IAEA Project Number RLA/5/054). 


\section{REFERENCES}

[1] ZMOZINSKI, A. V.; LLORENTE-MIRANDES, T.; DAMIN, I. C.; LÓPEZ-SÁNCHEZ, J. F.; VALE, M. G. R.; WELZ, B.; SILVA, M. M. Direct solid sample analysis with graphite furnace atomic absorption spectrometry - A fast and reliable screening procedure for the determination of inorganic arsenic in fish and seafood. Talanta, v. 134, p. 224-231, 2015.

[2] DOMINGO, J. L. Nutrients and chemical pollutants in fish and shellfish. Balancing health benefits and risks of regular fish consumption. Crit Rev Food Sci, v. 56, p. 979-988, 2016.

[3] PORTAL BRASIL. Consumo do pescado no Brasil aumenta 23,7\% em dois anos. Distrito Federal, Brasília, Brasil. 2013. Available at: <http://www.brasil.gov.br/economia-eemprego/2013/10/consumo-de-pescado-no-brasil-aumenta-23-7-em-dois-anos>. Last accessed at $17 \mathrm{Jul} 2017$.

[4] CORRAlES, D.; ACUÑA, A.; SAlHI, M.; SAONA, G.; BRUGNOLI, E. Copper, zinc, mercury and arsenic content in Micropogonias furnieri and Mugil platanus of the Montevideo coastal zone, Río de la Plata. Braz J Oceanogr, v. 64, p. 57-65, 2016.

[5] YI, Y.; TANG, C.; YI, T.; YANG, Z.; ZHANG, S. Health risk assessment of heavy metals in fish and accumulation patterns in food web in the upper Yangtze River, China. Ecotox Environ Safe, v. 145, p. 295-302 2017.

[6] MORGanO, M. A.; DE Oliveira, A. P. F.; RABONATO, L. C.; MILANI, R. F.; VASCONCELlOS, J. P.; MARTINS, C. N.; CITTI, A. L.; TELLES, E. O.; DE CARVALHO BALIAN, S. Avaliação de contaminantes inorgânicos (As, $\mathrm{Cd}, \mathrm{Cr}, \mathrm{Hg}$ e $\mathrm{Pb}$ ) em espécies de peixes. Rev Inst Adolfo Lutz, v. 70, p. 497-506, 2011.

[7] OKEN, E.; CHOI, A. L.; KARAGAS, M. R.; MARIËN, K.; RHEINBERGER, C. M.; SCHOENY, R.; SUNDERLAND E.; KORRICK, S. Which fish should I eat? Perspectives influencing fish consumption choices. Environ Health Persp, v. 120, p. 790-798, 2012.

[8] NEFF, M. R.; BHAVSAR, S. P.; NI, F. J.; CARPENTER, D. O.; DROUILLARD, K.; FISK, A. T.; ARTS, M. T. Risk-benefit of consuming Lake Erie fish. Environ Res, v.134, p. 57-65, 2014. 
[9] IAEA - International Atomic Energy Agency. Cooperation Report for 2012. Project Number RLA/5/054, ARCAL CIII. Austria: IAEA, 2013. 96p.

[10] MOREIRA, E. G.; VASCONCEllos, M. B.; MAIHARA, V. A.; CATHARINO, M. G.; SAIKI, M. Interlaboratory comparison for the characterization of a Brazilian mussel reference material. J. Braz. Chem Soc, v. 29, p. 823-830, 2018.

[11] NIST - National Institute of Standards and Technology - Certificate of Analysis Standard Reference Material 1566b Oyster Tissue, USA: NIST, 2001. 5p.

[12] CHU, S. Y. F.; EKSTRÖM L. P.; FIRESTONE, R. B. The Lund/LBLN Nuclear Data Search: Nuclide search, USA and Sweden, 1999, Available at <http://nucleardata.nuclear.lu.se/toi/>. Last Accessed 06 May 2017.

[13] THOMPSON, M. Recent trends in inter-laboratory precision at ppb and sub-ppb concentrations in relation to fitness for purpose criteria in proficiency testing. Analyst, v. 125, p. 385386, 2000.

[14] BODE, P. Instrumental and organization aspects of a neutron activation analysis laboratory, The Netherlands, 1996, Available at <https://repository.tudelft.nl/islandora/object/uuid\%3A438b9110-fb94-4015-b2771c5fba96ac71>. Last Accessed 05 April 2018.

[15] FABIANO, K. C.; LIMA, A. P.; VASCONCELlOS, M. B.; MOREIRA, E. G. Contribution to food safety assurance of fish consumed at São Paulo city by means of trace element determination. J Radioanal Nucl Chem, v. 309, p. 383-388, 2016.

[16] ANVISA - Agência Nacional de Vigilância Sanitária. Resolução. RDC No. 42. de 29 de agosto de 2013. Dispõe sobre o Regulamento Técnico MERCOSUL sobre Limites Máximos de Contaminantes Inorgânicos em Alimentos, Distrito Federal: ANVISA, 2013. 3p.

[17] FSANZ - Food Standards Australia New Zealand. Maximum levels of contaminants and natural toxicants, Australia and New Zealand: FSANZ, 2017, 7p. 